Filarecka Agnieszka, Jęchorek Michal. Dynamic taping in damage to the long thoracic nerve - proposal proceedings. Journal of Education, Health and Sport. 2020;10(9):882-891. eISSN 2391-8306. DOI http://dx.doi.org/10.12775/JEHS.2020.10.09.107

https://apcz.umk.pl/czasopisma/index.php/JEHS/article/view/JEHS.2020.10.09.107

https://zenodo.org/record/4057178

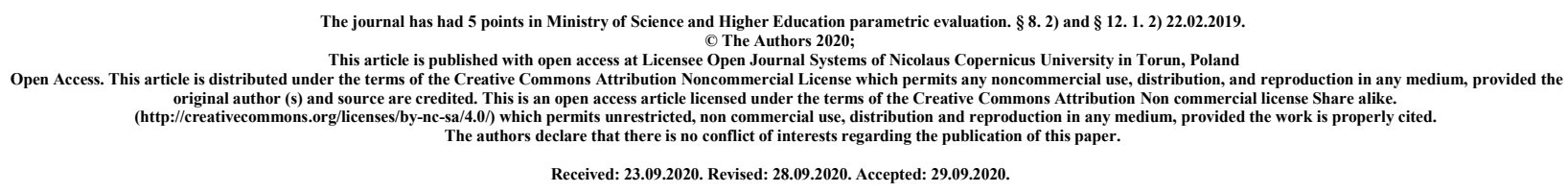

\title{
Dynamic taping in damage to the long thoracic nerve - proposal proceedings
}

\author{
Agnieszka Filarecka ${ }^{1}$, Michał Jẹchorek ${ }^{2}$
}

Chair and Clinic of an Oncological Surgeon, Collegium Medicum of the Nicolaus Copernicus University in Toruń

ToTu addiction therapy and treatment center in Karnice

\section{Corresponding author:}

mgr Agnieszka Filarecka

Collegium Medicum, UMK Bydgoszcz, hair and Clinic of Oncological Surgery

Ul. Izabeli Romanowskiej 2, 85-796 Bydgoszcz, Poland

Tel. 503074346

e-mail: aga.filarecka@gmail.com

\begin{abstract}
Breast cancer is a leading cancer among women, high incidence of cancer is not synonymous with high mortality. Women who undergo radical or partial mastectomy after surgery want to return to full fitness as soon as possible. Movement restrictions associated with the procedure do not have a positive effect on the patients' psyche.
\end{abstract}


One of the complications of surgery in the armpit is long pectoral nerve damage. Impaired mechanics of the shoulder blade affect non-ergonomic movement in the shoulder joint. Using the neurorehabilitation methods, the correct scapula pattern should be restored. Facilitation, i.e. tracking, is also an effective method for peripheral nerve damage. In each of the methods, the movement is supported by a therapist, who can determine the direction of movement through resistance, or support it.

The study presents examples of kinesiotaping applications that can be used in therapy at various stages. The method of use depends on the degree of damage to the structure and should be modified for therapy.

A review of available literature and own experience were used for the work.

Key words: mastectomy, nerve damage, rehabilitation, kinesiotaping

\section{Introduction}

Breast cancer is the most common cancer in women. In a significant number of cases it requires radical surgical treatment. The method of treating cancer depends on the stage of the disease. One of the most common postoperative complications, apart from lymph flow disorders, is damage to the long pectoral nerve during mastectomy or breast-saving surgery [1].

Stress associated with the disease affects the overlap of physical ailments [2].

Due to the surgery, we can distinguish as adverse effects [2,3]:

- Change of attitude

- Restriction of mobility in the joints of the rim of the upper limb,

- Secondary lymphoedema,

- Decreased muscular strength of the operated side.

Depressed mood promotes even greater visibility of muscle weakness in the limb after surgery [2].

As a result of lymph node removal, during surgery, lymph flow is impaired, causing lymphoedema [3]. Pathological edema in itself reduces motor activity and causes further weakening of muscular strength due to immobility.

Another complication is damage to the long pectoral nerve, which is responsible for the innervation of the anterior dentate muscle. His dysfunction manifests itself in the protruding shoulder blade. scapula alata. This dysfunction, in addition to the visual effect, significantly affects the mechanic of 
the shoulder joint. The lack of a stable shoulder blade sliding on the posterior shear of the chest reduces mobility in the shoulder joint and the non-ergonomic work of the shoulder joint, which manifests itself in pain.

During the rehabilitation of patients after surgical treatment of breast cancer, particular attention should be paid to the symptoms of the protruding scapula, especially in patients who signal a decrease in the range of motion in the upper limb.

Therapeutic improvement should be adapted so that it would act comprehensively on all adverse effects [3].

In the exercise programs available to patients, the main focus is on the problem of secondary lymphoedema. Self-draining instructions apply. Forgetting about limiting mobility in the joints of the upper limb, reducing muscle strength and changing posture [4].

Rehabilitation after mastectomy should take place as early as possible to prevent muscle atrophy in the area of the operated limb, which may also contribute to a reduced lymph passage.

\section{Literature review}

Available literature does not present the use of the method in post-mastectomy rehabilitation therapy as a comprehensive therapy.

Mention of use of the method is noted in the case of damage to the brachial plexus or long pectoral nerve. The paper presents a proposal to use the method in patients without peripheral nerve damage, at various stages of therapy after surgery.

\subsection{Kinesiotapping method}

Kinesiotaping is a method of natural therapy that was developed by Dr. Kenzo Kase in Japan. This method of spreading around the world has been around since 1963. Its initial application was mainly promoted in sports medicine. There are currently a number of reports on the use of the method in other clinical specialties. The method uses cotton tapes with a special fiber weave structure that allows the tape to stretch to $140 \%$ of its original length. Thanks to waterproof properties, they can be used for several days and are not a restriction on the use of hydrotherapy treatments.

The cause of many problems within the musculoskeletal system is limited (slowed) blood and lymph flow as well as thickening of body fluids in the subcutaneous layer. The mechanism used by the kinesiotaping method raises and folds the epidermis along with the papillary layer of the dermis. This, in turn, leads to increased blood flow within the sub-papillary vascular network and in the deep vessels of the skin, and multiplication of lymph transport, ranging from the capillary lymph nipples through the sub-chordal lymphatic network to the blood vessels. Thanks to this, more favorable conditions are created for regeneration within the areas affected by the disease process. 
As a result, muscle and fascial tension are normalized, blood and lymph flow are activated, pain is reduced and motor skills are improved [5]

The following techniques depending on clinical indications are used in the kinesiotaping method [6]:

- Mechanical correction - is aimed at increasing muscle tone and increasing tissue elasticity. The patch should be cut and given the shape of the letter $\mathrm{Y}$ with a short base and elongated arms. The application of the patch tape begins, depending on the indications, on the base or arms. The application uses a stretch from $50-70 \%$ of the original length

- Fascia correction aims to reduce muscle tone. The application follows the maximum extension of the structures covered by the application. The tape is glued with a stretch of 25 to $50 \%$.

- Local (space correction) applied only to places affected by the inflammatory process and painful points with a local location. The patch should be stretched 25 to $50 \%$.

- Ligament / tendon correction, developed to stimulate mechanoreceptors and increased prioprioreceptive thoracies that should normalize ligament and tendon tension. It is charged after previous mechanical correction. Patch tension should be $25-50 \%$ at bases and up to $100 \%$ during tape run.

- Functional correction applied in restrictions of mobility and improper positioning of individual body segments hindering their functioning. The application follows the correction setting.

- Lymphatic correction recommended for the prevention and therapy of lymphoedema. Multisection slicing should be used and the patch should be applied with the base part in the area of the lymph nodes. Tape tension used in this technique ranges from $0-10 \%$.

Depending on the application needs, the tapes can be freely adapted to the application site by cutting them. The literature applications used in therapy appear as the letters $\mathrm{Y}, \mathrm{X}, \mathrm{V}$, as well as "Fan" and "Web" applications.

Correct application of the patch to the skin surface depends on the clinical condition of muscle tissues and fascia. Two techniques are recommended:

- loosening technique, recommended in acute conditions with increased muscle tone and major pain - strengthening technique, recommended in chronic conditions with muscle weakness. Before applying the patch, cleanse the skin and remove excess hair. These treatments will ensure a longer duration of the patch on the skin. The duration of application depends on the application method and patient activity.

Each clinical application should be planned and conditioned by clinical indications. The therapist must determine the strategy of the procedure, in which he should choose the technique of cutting and applying the patch, determine the place and direction, and determine the percentage of its stretching. 
According to existing diagnostic standards, its purpose should be determined in therapy. For this purpose, we can use the ICF classification.

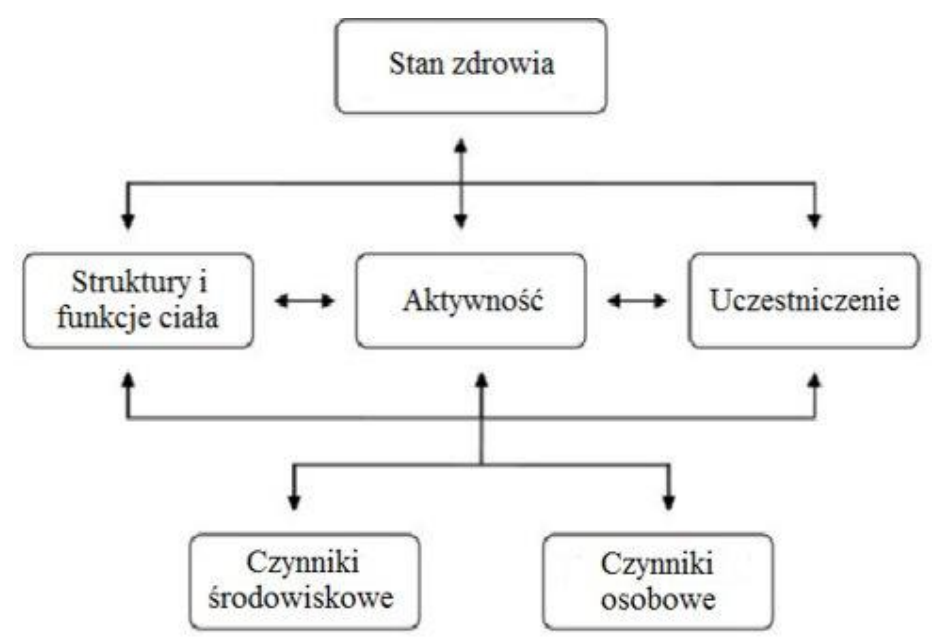

Dig. 1. ICF classification scheme

The improvement process should primarily include:

- $\quad$ Patient needs

- $\quad$ Patient's capabilities

- General condition of the patient

\subsection{Damage to the long pectoral nerve}

The long pectoral nerve is one of the most frequently damaged upper body nerves. It is formed from the branches of the abdominal spinal nerves in the cervical spine (C5-C7), which, coming out of the spinal cord, follow the shoulder forming the brachial plexus. The long pectoral nerve, after leaving the plexus, passes through the medial inclined muscle and, running along the lateral side of the chest, innervates the anterior dentate muscle. This muscle pushes the shoulder blade forward, stabilizing it on the chest [7].

Anterior pectoral neuropathy causes a dysfunction called the winged scapula. The symptom is a characteristic shoulder blade extension (Fig. 2), especially noticeable when the limb is extended and supported, e.g. on a wall. The checking test is the extension of the upper limb in a forward bend [8]. 


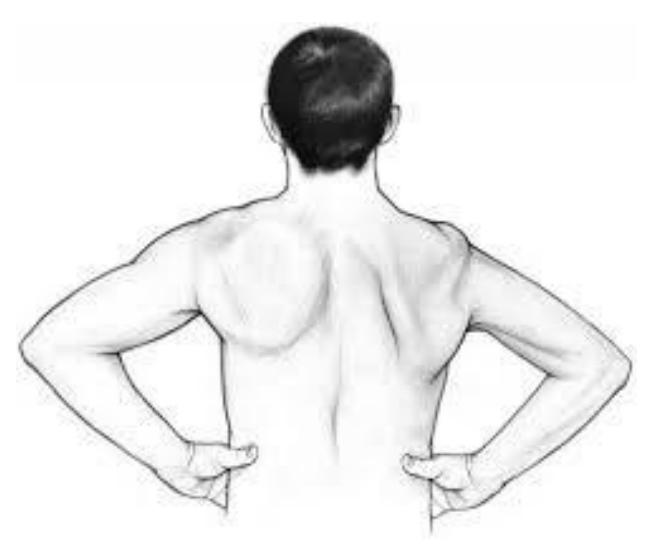

Fig. 2. Scapula alate

Compared to other brachial plexus nerves, this nerve has smaller dimensions, a smaller amount of connective tissue, and a relatively superficial location. The risk of damage is increased due to the long distance the nerve travels (Fig. 3)

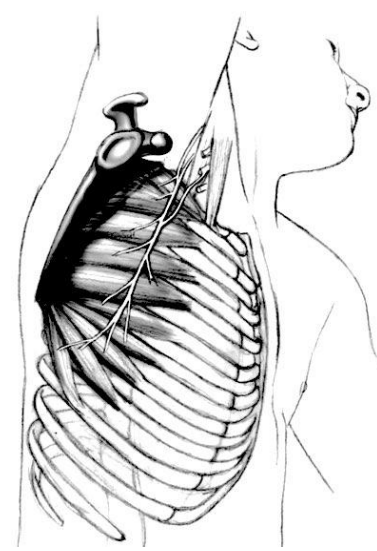

Fig. 3. Long course of the pectoral nerve

Rehabilitation plays a major role in nerve damage. Stimulation of the anterior dentate muscle with kinesitherapy is a key element in reducing muscle dysfunction. Paving nerve function also affects its faster regeneration. Electrostimulation is another method of stimulating the muscle to contract, however, due to the oncological past, stimulation with physical factors is inadvisable in women after mastectomy. An important element is maintaining proper mobility and mechanics of the work of the upper limb rim. 


\section{Therapy after mastectomy}

Using diagnostic tools, we can plan therapy for women after mastectomy. When planning your therapy, find out the root cause of the dysfunction and develop a strategy to address the cause.

ICF classification in the context of rehabilitation of women after mastectomy can be used as follows: Patient's basic problem: I can't reach the glass from the cabinet. This function is considered at the level of participation - participation in the ICF classification.

During diagnostics, the therapist diagnoses the cause of the patient's problem, i.e. sets the dysfunction at the level of activity and then the structure that disturbs the activity.

This scheme can be saved as follows:

At the structure level:

No slippage between the major pectoral muscle and the scar formed after the surgical incision.

At the activity level:

Limitation of bending of the upper limbs, visit and external rotation

At the participation level:

No possibility to reach the glass from the cabinet

The Kinesiotaping method as a method supplementing therapy after work on a disturbed structure is aimed at maintaining a longer therapeutic effect so that the correct movement pattern is fixed. Depending on the therapeutic program, therapy can begin with a limitation related to activity by affecting the damaged structure or from the damaged structure by affecting
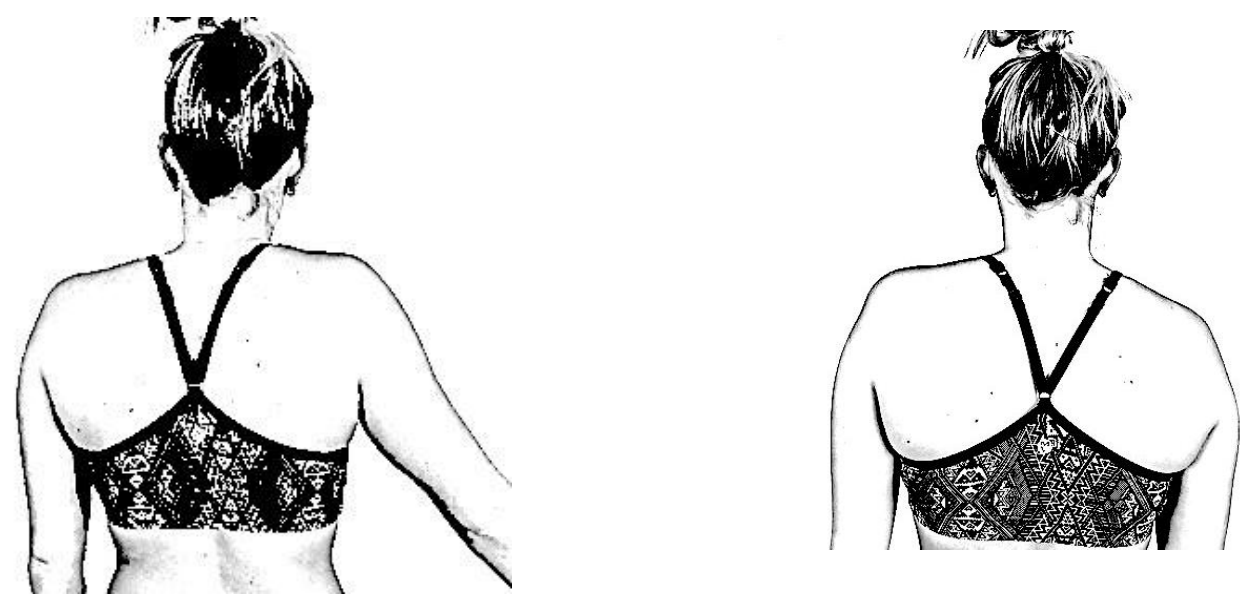

Fig. 4. Manifestation of damage to the right pectoral nerve on the right side of a woman after mastectomy [own collection] 
The therapists' task is to find the problem at the level of activity and structure.

In the first stage after surgery, it is recommended to use techniques in which there is no movement but isometric muscle tension. Work on distant structures and transfer of tension from the pelvis, second upper limb, shoulder blades of the lower limbs, to the shoulder girdle, can also be effectively used in the first stage of therapy.

At a later stage, working on the stability of the shoulder blade, we can use the supports on the forearm of the operated limb. We can use the supports in sitting in lying on the side or lying on the back or stomach. The variety of kinesitherapy methods makes it possible to stimuli and constantly stimulate the nervous system. In order to maintain the

2 effect $\begin{array}{lr}\text { change } \\ \text { of }\end{array}$ kinesitherapy, you can use 2 slicing or kinesiotaping. 3 The dynamic slicing method presented below was
1 used after one hour of 1 stimulation by kinesitherapy using available kinesitherapy methods.
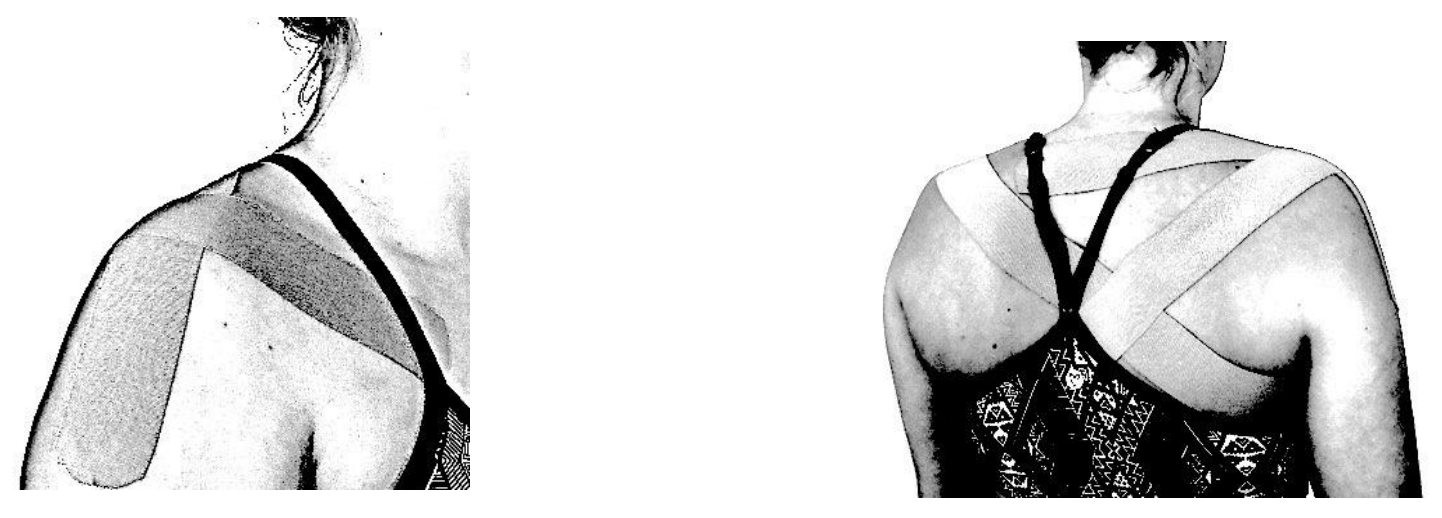

Fig. 5. Tape applications

Of the techniques used in plastering, the fascial, mechanical, ligament and functional techniques were used depending on the stage of therapy of the application site. In order to increase muscle tone, a mechanical method was used to mechanically lift the shoulder blade and strengthen the action of the anterior toothed muscle (1). The application applied to the muscle was also aimed at stabilizing the scapula and restoring the proper track of the scapula. The fascial method used relieved the pectoral muscle (2) so as to position the head of the humerus centrally in the joint. This application was aimed at restoring muscle balance between antagonists. The ligament technique was used at the head of the humerus to support knitting of the deltoid muscle (1). Functional positioning of the blade was corrected by the application setting the lower edge of the blade in the direction of the spine to strengthen the operation of other applications (3) 
After using six-month therapy with kinesitherapy and strengthening it with kinesitherapy, better movement mechanics in the shoulder joint and a reduction in the deficit associated with damage to the long pectoral nerves were obtained.

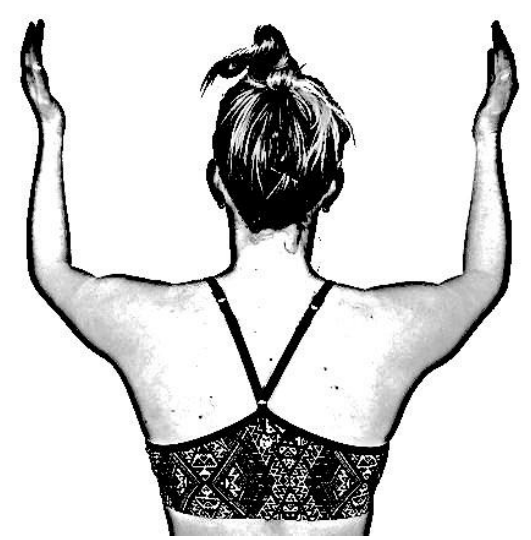

Fig. 6. The effect of therapy and the upward limb elevation test

\section{Conclusions}

The study shows that in women in whom, after stimulation of the toothed muscle through neurorehabilitation methods, the use of tapes may result in maintaining the therapeutic effect, which affected the better mechanics of the scapula glide and increased range of motion in the shoulder joint. The Kinesiotaping method can be used as a complementary therapy, as it has no contraindications for use in oncological patients compared to complementary physical methods used in this area, i.e. electrostimulation.

\section{Literature:}

1. Jassem J. Krzakowsk M. (red) Rak piersi. [W]: Krzakowski M. Warzocha K. (red.) Zalecenia postẹpowania diagnostyczno-terapeutycznego w nowotworach złośliwych 2013 . Via Medica, Gdańsk 2013; 213, 230-236

2. Hawro R. Matkowski R. Rehabilitacja po leczeniu raka piersi. [W]: Woźniewski M. Kornafel J. (red.). Rehabilitacja w onkologii. Elsevier Urban \& Partner, Wrocław 2010; 181-197

3. Tchórzewska H., Rehabilitacja w leczeniu raka piersi. [W] Pawlicki M. (red.). Rak piersi nowe nadzieje i możiwości leczenia. Wyd. 2. Alfa Medica-Press, Bielsko-Biała 2011; 99-120.

4. Tchórzewska H, Fizjoterapia w leczeniu chorych na raka. [W]: Szukiewicz D. Fizjoterapia w ginekologii i położnictwie, Wydawnictwo Lekarskie PZWL, Warszawa 2012, 160-172

5. Kinesio Taping Association. Kinesio Taping® Basic Course. 2010 
6. Zagłoba-Kaszuba A., Huber J., Stryła W. i wsp.: Analiza elektromiograficzna czynności miẹśni kończyn dolnych w trakcie wykonywania wzorców PNF. [W]: Huber J., Wytrążek M., Kabsch A. (red.), Kierunki rozwoju neurofizjologii klinicznej $i$ fizjoterapii $i$ terapii manualnej. , Wydawnictwo Naukowe Uniwersytetu Medycznego im. Karola Marcinkowskiego w Poznaniu, 2010, 104-113

7. Bochenek A. Reicher M. Anatomia czlowieka, Tom 4, Wydawnictwo Lekarskie PZWL, Warszawa 2010

8. Berny W, Jamundowicz W, Rutkowski R, Neurotraumatologia czẹść 1 - Urazy krẹgostupa, rdzenia krẹgowego i nerwów obwodowych, UM Wrocław, Wroclaw 2009

9. Lupa A. Badania pacjenta zgodnie z wytycznymi ICF. Praktyczna Fizjoterapia i Rehabilitacja 2010; 5: 27-33 